\title{
ABO and Rhesus Types of Blood Group Distribution in Blood Donors in Blood Bank, Government Medical College and Hospital-Suryapet, Telangana: A Tertiary Care Centre Study
}

\author{
Reddy M.K. ${ }^{1}$, K. Raja Kumar ${ }^{2}$, Reddy D.S. ${ }^{3}$ \\ ${ }^{1}$ Dr. Madhukar Reddy Kadaru, Assistant Professor, ${ }^{2}$ Dr. K. Raja Kumar, Assistant Professor, Department of Pathology, \\ Government Medical College, Suryapet, Telangana, ${ }^{3}$ Dr. D. Smitha Reddy, Associate Professor, all authors are affiliated \\ with Department of Pathology, Government Medical College, Suryapet, Telangana, Andra Pradesh, India.
}

Corresponding Author: Dr. K. Raja Kumar, Associate Professor, Department of Pathology, Government Medical College, Suryapet, Telangana, Anadra Pradesh, India. E-mail: mkadaru@gmail.com

\begin{abstract}
Aims and objectives: To study the distribution and frequencies of ABO and Rhesus (Rh) blood groups among blood donors, who participated in indoor and outdoor blood donation camps organized by suryapet blood bank, Government medical college-suryapet, Telangana. ABO and Rh typing is very important for proper functioning and safe blood banking. Materials and Methods: A Three-year retrospective study was carried out at suryapet blood bank, Telangana, during 3-year period from January 2016 to December 2018 and the total number of blood units collected was 7,035. The donors were screened and who are medically fit are accepted for blood donation. Blood group of the blood donors was determined by forward grouping and reverse grouping methods with the help of commercially available standard monoclonal antisera. Results: The most common blood group among donors was "O" (43.90\%) followed by " B" (32.50\%), "A" (17.95\%) and the least prevalent blood group was "AB" (05.62\%). Maximum number of blood donors were Rh positive $(95.72 \%)$ while Rh negative were only $(04.27 \%)$. There was a higher rate of male donors than female donors. Conclusion: The present study concludes that most common blood group was "O" positive and the least common is "AB". This data helps in appropriate maintenance of inventory in the blood bank and also plays important role in patients health care.
\end{abstract}

Keywords: ABO, Blood Groups, Blood Donors, Rhesus (Rh), Genes.

\section{Introduction}

Each individual has different blood groups. The ABO blood group system is divided in to four blood types on the basis of presence or absence of $\mathrm{A}$ and $\mathrm{B}$ surface antigens determined by $\mathrm{ABO}$ genes, located on chromosome $9 \mathrm{q}$ with anti-A and anti-B antibodies in serum of individuals lacking the corresponding antigen [1].

ABO blood group discovered by Karl Landsteiner for which he received Noble prize followed by weiner discovery of Rh (D) antigens. After Von Decastello and Sturli discovered the fourth Type Blood Group AB [2]. The cause of Haemolytic disease of foetus and Newborn (HDFN) was linked to the Rh Blood group which is very essential in Obstetrics [3]. Blood groups are genetically determined, inherited in a simple mendelian fashion and are useful in paternity testing,

Manuscript received: $2^{\text {nd }}$ March 2019

Reviewed: $11^{\text {th }}$ March 2019

Author Corrected: $16^{\text {th }}$ March 2019

Accepted for Publication: $20^{\text {th }}$ March 2019 legal medicine, immune haematology, blood transfusions, unmatched pregnancy. Disease such as duodenal ulcer, Diabetes mellitus, urinary tract infection are known to have some association with blood groups [4].

The prevalence of $\mathrm{ABO}$ Blood groups varies from region to region and race to race. Data regarding $\mathrm{ABO}$ blood group distribution is very important for effective management of safe blood transfusion services and Blood bank.

Therefore it is essential to have Knowledge regarding distribution of these blood groups in the population of this study region and hence this study has been carried out to determine the frequency and distribution of $\mathrm{ABO}$ and $\mathrm{Rh}$ blood groups in blood donors of tertiary care hospital of Government Medical College and HospitalSuryapet, Telangana and to compare with other studies [3][5]. 


\section{Materials and Methods}

This retrospective study was carried out with 7,035 blood donors aged between 18 to 65 years. These donor subjects had donated blood in Suryapet blood bank, Government Medical College and General Hospital, Suryapet and voluntary blood donation camps organized from January 2016 to December 2018, i.e for three years.

All the donors were screened and interviewed for health history, medical history including previous transfusions, the donors who are medically fit are accepted for donations. Blood group of the blood donors was determined by forward grouping (cell grouping) and reverse grouping (serum grouping) by test tube agglutination methods with the help of commercially available standard monoclonal antisera A, anti sera B, antisera $\mathrm{O}$ after validation of the antisera at blood bank.

Reverse blood grouping was performed by test tube agglutination method with pooled known $\mathrm{A}, \mathrm{B}$, and $\mathrm{O}$ cell types that are prepared by the blood bank daily. If the both forward (cell group) and reverse (serum group) grouping are identical than the final blood group is confirmed. Rh negative blood group were confirmed by anti globulin technique (Du test). All Du positive were considered as $\mathrm{Rh}$ positive group.

The donor blood group data is recorded, tabulated, analysed and compared with similar studies with other authors.

\section{Original Research Article}

Sampling Technique: $\mathrm{ABO}$ and $\mathrm{Rh}$ grouping was performed for each sample using tube agglutination method according to our standard operating procedure. The reagents used were anti- $\mathrm{A}$, anti- $\mathrm{B}$, anti- $\mathrm{AB}$ and anti-D manufactured by Tulip Diagnostics (Tulip Diagnostics (P) Ltd, Verna, Goa, India). All blood group $\mathrm{O}$ donors were tested by anti-H lectin (Tulip Diagnostics (P) Ltd, Verna, Goa, India) to rule out Bombay blood group. All antisera used were monoclonal reagents and were used after subjecting it to quality control test. A cells, B cells and O cells prepared in house for reverse grouping were pooled from three different known donor samples.

Inclusion Criteria: should be in Good health, more than $45 \mathrm{~kg}$, haemoglobin more than $12 \mathrm{gms}$, no history of recent surgery, negative for pre donation screening for Transfusion transmitted infections.

Exclusion criteria: Not included in the study are positive for transfusion transmitted infections, hypertensive patients on medications, tuberculosis, kidney diseases, heart diseases, cancer, liver diseases, leprosy.

Statistical analysis: the data was analyzed by using simple percentages and frequencies. Frequency and percentage for each variable were calculated and $95 \%$ confidence intervals $(\mathrm{CI})$ were taken to define normal range.

\section{Results}

ABO Blood groups of 7,035 healthy blood donors, from January 2016 to December 2018 with 18 to 65 years of age group was studied out. The three year Retrospective study revealed that out of 7,035 blood donors majority were 7,014 $(99.70 \%)$ male donors and 21(0.29\%) were female donors (Table No -1). Most of the donors were in the age group of $20-40$ years.

The distribution of blood groups of donors were, Blood group A (17.95\%), B (32.50\%), O (43.90\%) and AB (5.62\%). In ABO system our study shows the highest frequency of blood group "O" (43.90\%), Followed by blood group B (32.50\%), blood group A (17.95\%) and Blood group AB (5.62\%) (Table No-2).

In $\mathrm{Rh}$ system, our study shows frequency of $\mathrm{Rh}$ positive (were most common blood group with $(95.72 \%)$ while $\mathrm{Rh}$ negative is only (4.27\%) respectively (Table no-2).

Table No-1: Gender distribution among blood donors.

\begin{tabular}{|c|c|c|c|c|}
\hline Gender & \multicolumn{4}{|c|}{ Gender distribution in each year } \\
\hline & $\mathbf{2 0 1 6}$ & $\mathbf{2 0 1 7}$ & $\mathbf{2 0 1 8}$ & Total (\%) \\
\hline Male donors & 2562 & 2781 & 1671 & $7014(99.70 \%)$ \\
\hline Female donors & 08 & 03 & 10 & $21(0.30 \%)$ \\
\hline Total donors & $\mathbf{2 5 7 0}$ & $\mathbf{2 7 8 4}$ & $\mathbf{1 6 8 1}$ & $\mathbf{7 0 3 5}(\mathbf{1 0 0 \% )}$ \\
\hline
\end{tabular}




\section{Original Research Article}

Table No-2: Distribution of ABO Blood groups and Rhesus types among blood donors

\begin{tabular}{|c|c|c|c|}
\hline \multirow{2}{*}{ Blood groups } & Number and percentage (\%) distribution of Various Blood groups & \multirow{2}{*}{ Total (\%) } \\
\cline { 2 - 3 } & Rhesus postive & Rhesus negative & \\
\hline A & $1208(17.17 \%)$ & $55(0.78 \%)$ & $1263(17.95 \%)$ \\
\hline B & $2198(31.24 \%)$ & $89(1.26 \%)$ & $2287(32.50 \%)$ \\
\hline O & $2950(41.93 \%)$ & $139(1.97 \%)$ & $3089(43.90 \%)$ \\
\hline AB & $378(5.37 \%)$ & $18(0.25 \%)$ & $396(5.62 \%)$ \\
\hline Total (\%) & $\mathbf{6 7 3 4}(\mathbf{9 5 . 7 2 \% )}$ & $\mathbf{3 0 1}(\mathbf{4 . 2 8 \% )}$ & $\mathbf{7 0 3 5}(\mathbf{1 0 0 \% )}$ \\
\hline
\end{tabular}

\section{Discussion}

The current study helps us to ensure the knowledge of the distribution of ABO and Rh blood groups in the suryapet blood bank area.

Table-3: Comparative study on prevalence of $\mathrm{ABO}$ and $\mathrm{Rh}$ phenotypes in different regions of India (in percentages).

\begin{tabular}{|c|c|c|c|c|c|c|c|}
\hline \multirow[t]{2}{*}{ Region } & \multirow{2}{*}{$\begin{array}{l}\text { Place of study, } \\
\text { (Author, year) }\end{array}$} & \multicolumn{4}{|c|}{ ABO Blood Group } & \multicolumn{2}{|c|}{ Rhesus Group } \\
\hline & & $\mathbf{A}$ & B & $\mathbf{O}$ & $\mathbf{A B}$ & POS.(+) & $\operatorname{Neg}(-)$ \\
\hline \multirow{6}{*}{$\begin{array}{l}\text { South } \\
\text { India }\end{array}$} & Suryapet, (Present study,2019) & 17.95 & 32.50 & 43.90 & 5.62 & 95.72 & 4.27 \\
\hline & Tirupathi (Khader F et al. 2018) [2] & 6.98 & 42.61 & 45.59 & 4.80 & 95.96 & 4.03 \\
\hline & Davanagere(Mallikarjuna et al.,2012)[6] & 26.15 & 29.85 & 31.76 & 7.24 & 94.8 & 5.2 \\
\hline & Shimoga (Girish c et al. ,2011) [7] & 24.27 & 29.43 & 39.17 & 7.13 & 94.93 & 5.07 \\
\hline & Bangalore (Periyavan et al.,2010) [8] & 23.85 & 29.95 & 39.82 & 6.37 & 94.2 & 5.8 \\
\hline & Tirupathi (Suresh et al., 2015) [9] & 20.0 & 32.2 & 41.7 & 6.1 & 96.9 & 3.1 \\
\hline \multirow{4}{*}{$\begin{array}{l}\text { North } \\
\text { India }\end{array}$} & Haryana ( pawwan et al.,2015) [10] & 22.90 & 38.83 & 28.70 & 9.54 & 90.79 & 9.28 \\
\hline & Uttarakhand( Garg P et al.,2014) [11] & 28.70 & 32.07 & 28.70 & 10.53 & 94.49 & 5.51 \\
\hline & Amritsar (Kaur H et al.,2013) [12] & 18.01 & 38.06 & 34.31 & 9.62 & 91.28 & 8.72 \\
\hline & Lucknow (Chandra et al., 2012) [13] & 21.73 & 39.84 & 29.10 & 9.33 & 95.71 & 4.29 \\
\hline \multirow{2}{*}{$\begin{array}{c}\text { Central } \\
\text { India }\end{array}$} & Indore (Gupta NK et al.,2012) [14] & 24.15 & 35.25 & 31.05 & 9.01 & 95.43 & 4.57 \\
\hline & Bhopal (Rajesh et al.,2015) [15] & 22.52 & 35.92 & 30.99 & 10.55 & 95.42 & 4.57 \\
\hline \multirow{2}{*}{$\begin{array}{l}\text { East } \\
\text { India }\end{array}$} & Durgapur(Nag et al.,2013) [16] & 23.90 & 35.60 & 34.80 & 7.70 & 94.70 & 5.30 \\
\hline & Ranchi (Singh A et al., 2016) [5] & 22.09 & 35.15 & 34.73 & 8.03 & 86.46 & 3.54 \\
\hline \multirow{3}{*}{$\begin{array}{l}\text { West } \\
\text { India }\end{array}$} & Rajasthan( Manish K et al.,2018) [17] & 15.46 & 39.95 & 35.68 & 8.80 & 91.17 & 8.82 \\
\hline & Gujarat (Rupali et al.,2017) [18] & 25.19 & 35.65 & 29.11 & 10.05 & 94.09 & 5.1 \\
\hline & Surat (Raja KA et al.,2016) [19] & 24.35 & 34.43 & 32.26 & 8.94 & 95.12 & 4.87 \\
\hline
\end{tabular}

Table No-4: Distribution of ABO and rhesus blood groups outside India.

\begin{tabular}{|c|l|c|c|c|c|c|c|}
\hline \multirow{2}{*}{ Region } & Place of study & \multicolumn{3}{|c|}{ ABO Blood Group } & \multicolumn{2}{c|}{ Rhesus Group } \\
\cline { 2 - 8 } & & $\mathbf{A}$ & $\mathbf{B}$ & $\mathbf{O}$ & AB & POS.(+) & Neg(-) \\
\hline \multirow{3}{*}{$\begin{array}{c}\text { Out side } \\
\text { India }\end{array}$} & Pakistan [20] & 27.92 & 32.40 & 29.10 & 10.58 & 90.13 & 9.87 \\
\cline { 2 - 8 } & Nepal [21] & 34.0 & 29.0 & 33.0 & 4.0 & 96.7 & 3.3 \\
\cline { 2 - 8 } & Britian [22] & 42.0 & 8.0 & 47.10 & 3.0 & 83.0 & 17.0 \\
\cline { 2 - 8 } & USA [23] & 41.0 & 9.0 & 46.0 & 4.0 & 85.0 & 15.0 \\
\cline { 2 - 8 } & Nigeria [24] & 21.60 & 21.40 & 54.20 & 2.80 & 95.20 & 4.80 \\
\cline { 2 - 8 } & Saudi Arabia [25] & 24.0 & 17.0 & 52.0 & 4.0 & 93.0 & 7.0 \\
\cline { 2 - 8 } & Iran [26] & 45.0 & 11.0 & 40 & 4.0 & 92.40 & 7.60 \\
\hline
\end{tabular}




\section{Original Research Article}

The comparison of frequency and distribution of $\mathrm{ABO}$ and Rh group in the blood donors of current study with similar studies done within India (Table no: 3) and outside of India (Table no: 4). The studies done in the south part of India by authors, Khader F et al and others [2,6-9], showed blood group "O" was commonest, followed by "B", "A" and "AB". The same frequency was found in our study i.e "O" was more frequent than "B" followed by " $\mathrm{A}$ " and "AB" blood groups.

In the studies done in North part of Other Indian authors observed B positive as most common blood group which is different than our study [10-19], showed blood group " $\mathrm{B}$ " is the commonest followed by $\mathrm{O}$, A, and AB, which is different from our study.

The distribution of blood in India shows that south India, "O" is the commonest blood group where as in North, East, West and Central India " $B$ " is the most frequent group.

In the studies done outside India Other authors observed B positive as most common blood group which is different than our study [21-26], the frequent blood group is "O", followed by "A", "B" ,and "AB". Except in the study done in Pakistan [20], the commonest blood group is " $\mathrm{B}$ " followed by "O", " $\mathrm{A}$ " and "AB".

The incidence of $\mathrm{Rh}$ positive and $\mathrm{Rh}$ negative is similar in all the studies conducted in India and out side India.

In all the studies conducted in India [2] [6-19] the female donors are very low when compared to male donors. This is might be because of social taboo, stigma, cultural habits, lack of awareness, lack of motivation and fear of donation and increase in deferral in female donors due anaemic conditions.

The physicians should have knowledge about prevalence of blood groups in there society so that they can treat in emergencies. In antenatal care it helps in children born with congenital hemolytic diseases. In ante natal care the rare blood groups like "AB" negative, the attendants can be warned in advance for arranging the rare blood group. This helps in patients and treating physician for better management of the cases.

The physician should also aware about distribution of blood groups in certain population as there is genetic association of specific blood groups to certain diseases in certain population. The persons with A blood group are more frequently affected by coronary heart diseases, ischemic heart diseases, venous thrombosis and atherosclerosis in contrast to the persons who are having the blood group " O" are having protective effect against these diseases [27] [28] 29]. Similarly when compared to non-"O" groups, the "O" group individuals have $14 \%$ reduced risk of squamous cell carcinoma and $4 \%$ reduced risk of basal cell carcinoma [30]. There is also reduced risk of pancreatic cancer in blood group "O" individuals [31] [32]. The " $B$ " antigen individuals are prone for increased risk for ovarian cancer [33]. Some studies states that blood group "O" individuals will have more prone to duodenal ulcer and mosquito bite transmitted infections [5]. It is also useful in population genetic studies, resolving medicolegal cases and preventive measures against the diseases which are associated with different blood groups.

\section{Conclusion}

It is concluded that among 7035 healthy blood donors we observed that the most common blood group was "O”, followed by "B"(32.50\%), “A”(17.95\%)) and "AB" (5.62\%)). Among Rhesus (Rh) positive were $(95.72 \%)$ and negative were $(04.27 \%)$. The study helps in patient health care, preparing data base for blood bank, drafting proper national transfusion policies.

This study helps in creating awareness as to which blood groups should be stored and given priority and knowledge of blood groups distribution is very important for health planners for drafting health polices to face the future health challenges in this region of India, for forensic and clinical studies in this population. The data generated in this study reveals why there is a deficiency of particular blood group in

particular a area and to encourage the donors for more frequent blood donations, in our study " $A$ " $R h$ positive individuals has to donate more frequently and this helps in reducing maternal mortality rate, anaemic children, thalasemia patients, acute haemoraghic conditions like road traffic accidents where is a urgent transfusion required. This study recommends to conduct similar well designed studies in other geographic area of India to determine the prevalence of blood group distribution in them.

Acknowledgement- I sincerely thank Dr. Madhukar Reddy for collecting the data from blood bank and preparing the manuscript preparation.

Funding: Nil; Conflict of Interest: None initiated Permission from IRB: Yes 


\section{References}

1. Soonam John. Prevalence of ABO and rhesus blood groups in blood donors: a study from a tertiary care centre in South Kerala. International Journal of Contemporary Medical Research2017;4(11):2314-2316.

2. Md Khader Faheem. Demographic Distribution and Prevalence of ABO and Rhesus Blood Groups in Blood Donors: Study from a Tertiary Care Centre in Southern Region of Andhra Pradesh. IOSR Journal of Dental and Medical Sciences (IOSR-JDMS), vol. 17, no. 7, 2018, pp 01-05.

3, Raja KA, Dobariya GH, Unagar CA, Pandya AN, Patel JN, Wadhwani SN. Frequency and distribution of $\mathrm{ABO}$ and $\mathrm{Rh}$ blood groups among blood donors in tertiary care hospital of South Gujarat, India. Int J Res Med Sci 2016;4:5377-81.

4, Badge SA, Ovhal AG, Azad K, Meshram AT. Distribution of blood groups in blood donors in the blood bank of Jagdalpur, Bastar district, Chhattisgarh. Med J DY Patil Univ 2017;10:32-5.

5. Singh A, Srivastava RK, Deogharia KS, et al. Distribution of $\mathrm{ABO}$ and $\mathrm{Rh}$ types in voluntary Blood donors in Jharkhand area as a study conducted by RIMS, Ranchi. J Family Med Prim Care. 2016 JulSep;5(3):631-636. doi: 10.4103/2249-4863.197319.

6. Mallikarjuna S. Prevalence of $\mathrm{ABO}$ and Rhesus blood group among blood donors. Indian J. Pub. Health, Research and Development. 2012:3(2):106-109.

7. Girish C J, Chandrashekhar TN, Ramesh Babu K, Kantikar SM.ABO and Rhesus blood group distribution among Malnad region blood donors Research and Reviews in Biomedicine and Biotechnology (RRBB). 2011;2(3):25-30.

8. Periyavan S, Sangeetha SK, Marimuthu P, et al. Distribution of ABO and Rhesus-D blood groups in and around Bangalore. Asian J Transfus Sci. 2010 Jan;4(1): 41. doi: 10.4103/0973-6247.59391.

9. B. Suresh, K.V. Sreedhar Babu, P. Chandra Mouli, R. Arun, D.S. Jothibai. Distribution of $\mathrm{ABO}$ and rhesus (D) blood group antigens among blood donors at a tertiary care teaching hospital blood bank in south India. J Clin Sci Res 2015; 4:129-35.

10. Pawan Singh Puja Sharma, Shivani Kalhan, Rahul Satarkar, Sheetal Gole and Neha Garg. Distribution of ABO blood group and Rh (D) factor among blood donors in Haryana. Int J BiomedAdvRes2015;6:249-52

\section{Original Research Article}

11. Garg P, Upadhyay S, Chufal SS, et al. Prevalance of ABO and Rhesus Blood Groups in Blood Donors: A Study from a Tertiary Care Teaching Hospital of Kumaon Region of Uttarakhand. J Clin Diagn Res. 2014 Dec;8(12):FC16-9.doi:10.7860/JCDR/2014/9794. 5355. Epub 2014 Dec 5.

12. Kaur H, Khanna A, Manjari M, et al. Prevalence of $\mathrm{ABO}$ blood groups and rhesus (Rh) factor in the population residing in and around Amritsar, Punjab (a 4-year study from June 2007 to June 2011). Asian J Transfus Sci. 2013 Jul; 7(2): 159. doi: 10.4103/09736247. 115591.

13. Chandra T, Gupta A. Frequency of ABO and rhesus blood groups in blood donors. Asian J Transfus Sci. 2012 Jan;6(1):52-3. doi: 10.4103/0973-6247.95057.

14. Gupta Narendra Kumar, Dadwal S. Distribution of ABO and Rhesus-D Blood groups. Asian J. Trans. Sci. 2012.V6;1:73.

15. Rajesh Kumar Chaurasia, Puja Sharma, Vivek Vikram Bharosey, Amit Haritwal, Shweeta Rana,G.K. Sawke, Shalaka Avasare, Nilima Sawke. A study of distribution of $\mathrm{ABO}$ and $\mathrm{Rh}$ Blood groups system among blood donors at a tertiary care hospital. J of Evolution of Med and Dent Sci. 2015; 4 (18): 313842.

16. Nag I, Das SS. ABO and Rhesus blood groups in potential blood donors at Durgapur Steel city of the district of Burdwan, West Bengal. Asian J Transfus Sci. 2012 Jan;6(1):54-5. doi: 10.4103/0973-6247.95059.

17. Manish Kumar. Distribution of Blood Groups in Blood Donors in The Blood Bank, Jhalawar Hospital \& Medical College Society, Jhalawar, Rajasthan. IOSR Journal of Dental and Medical Sciences (IOSR-JDMS), vol. 17 , no. 8,2018 , pp 29-33

18. Rupali Patil, Vandana Patel, Minesh B. Gandhi. Frequency and distribution of $\mathrm{ABO}$ and $\mathrm{Rh}$ Blood group antigens in healthy blood donors at the blood bank of a tertiary care hospital in Gandhinagar, Gujarat, India. Indian Journal of Pathology and Oncology. 2017; 4(4): 586-90.

19. Kruti A. Raja, Gopi H. Dobariya, Chirag A. Unagar, Amrish N. Pandya, Nitendra N. Patel, Sangita J. Wadhwani. Frequency and distribution of ABO and Rh blood groups among blood donors in tertiary care hospital of South Gujarat, India. Int J Res Med Sci. 2016; 4(12):5377-81. 
20. Khattak ID, Khan TM, Khan P, et al. Frequency of $\mathrm{ABO}$ and Rhesus blood groups in District Swat, Pakistan. J Ayub Med Coll Abbottabad. 2008 Oct-Dec; 20 (4):127-9.

21. Pramanik T, Pramanik S. Distribution of ABO and $\mathrm{Rh}$ blood groups in Nepalese medical students: a report. East Mediterr Health J. 2000 Jan;6(1):156-8.

22. Rao C, Shetty J. Frequency of abo and rhesus (D) blood groups in dakshina Kannada district of Karnataka - A study from rural tertiary care teaching hospital in south India. Nitte Univ J Health Sci 2014;4:3-4.

23. Mollison PL, Engelfriet CP, Conteras M. The Rh blood group system. In: Blood Transfusion in Clinical Medicine. 9th ed. Oxford: Black Well Scientific Publication; 1993.p. 2008-9.

24. Mwangi J. Blood group distribution in an urban population of patient targeted blood donors. East Afr Med J. 1999 Nov;76(11):615-8.

25. Bashwari LA, Al-Mulhim AA, Ahmad MS, et al. Frequency of $\mathrm{ABO}$ blood groups in the Eastern region of Saudi Arabia. Saudi Med J.2001Nov;22(11):1008-12

26. Torabizade Maatoghia J, Paridara M, Mahmodian Shoushtaria M, Kianib B, Noric B, Shahjahanib M, et al. Distribution of ABO blood groups and rhesus factor in a large scale study of different cities and ethnicities in Khuzestan province. Iran. Egypt J Med Hum Genet 2016;17:105-9.

\section{Original Research Article}

27. Khan MI, Micheal S, Akhtar F, et al. Association of ABO blood groups with glaucoma in the Pakistani population. Can J Ophthalmol. 2009 Oct;44(5):582-6. doi: 10.3129/i09-104.

28. Alam M. ABO and rhesus blood groups in potential blood donors at Skardu (Northern Areas). Pak J Pathol 2005;16:94 7 .

29. Khan MS, Subhan F, Tahir F, Kazi BM, Dil AS, Sultan S, et al. Prevalence of blood groups and Rh factor in Bannu District (NWFP) Pakistan. Pak J Med Res 2004;43:8-10.

30. Xie J, Qureshi AA, Li Y, Han J. ABO blood group and incidence of skin cancer. PLoS One. 2010 Aug 4;5(8):e11972. doi: 10.1371/journal.pone.0011972.

31. Amundadottir L, Kraft P, Stolzenberg-Solomon RZ, et al. Genome-wide association study identifies variants in the ABO locus associated with susceptibility to pancreatic cancer. Nat Genet. 2009 Sep;41(9):986-90. doi: 10.1038/ng.429. Epub 2009 Aug 2.

32. Gates MA, Wolpin BM, Cramer DW, et al. ABO blood group and incidence of epithelial ovarian cancer. Int J Cancer. 2011 Jan 15;128(2):482-6. doi: 10.1002 /ijc. 25339. Epub 2010 Mar 22.

33. Mehta N, Swadas B. Prevalence of ABO blood groups at Mahavir Heart Institute Surat. Asian J Trans Sci 2012;6:74.

\section{How to cite this article?}

Reddy M.K, K. Raja Kumar, Reddy D.S.ABO and Rhesus Types of Blood Group Distribution in Blood Donors in Blood Bank, Government Medical College and Hospital-Suryapet, Telangana: A Tertiary Care Centre Study. Trop J Path Micro 2019;5(3):126-131.doi:10.17511/jopm.2019.i03.03. 